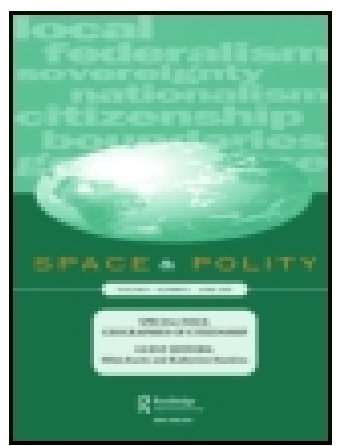

Space and Polity

\title{
Love, activism, and the possibility of radical social change in Mostar
}

\section{Giulia Carabelli}

To cite this article: Giulia Carabelli (2019): Love, activism, and the possibility of radical social change in Mostar, Space and Polity, DOI: 10.1080/13562576.2019.1634468

To link to this article: https://doi.org/10.1080/13562576.2019.1634468
(c) 2019 The Author(s). Published by Informa UK Limited, trading as Taylor \& Francis Group
曲 Published online: 27 Jun 2019.
Submit your article to this journal $\pi$

LII Article views: 192

View Crossmark data 


\title{
Love, activism, and the possibility of radical social change in Mostar
}

\author{
Giulia Carabelli \\ Max Planck Institute for the Study of Religious and Ethnic Diversity, Goettingen, Germany
}

\begin{abstract}
This article reflects on the meanings and possibilities of social change in Mostar, a city more often associated with the seeming impossibility of eradicating ethno-national divisions and corruption that paralyses it. It focuses on the under-researched politics of grassroots activism by drawing on Hardt's and Negri's work on the political potential of 'love' to shape and propel radical politics. Overall, the article reveals the lack of a cohesive agenda of grassroots politics in Mostar, and asks whether love (that creates and sustains political movement) can educate, patiently, to the revolution.
\end{abstract}

\section{ARTICLE HISTORY}

Received 5 May 2019

Accepted 16 June 2019

\section{KEYWORDS}

Grassroots activism; divided cities; Mostar; social change; love

\section{Introduction}

The city of Mostar was officially reunited in 2004, with some progress made in restructuring the parallel administrations that crystallised in the aftermath of the conflict, garnering important results such as the formation of a united city council and mayoral office (Carabelli, 2018, pp. 41-83). This process of reunification has been largely instructed by the Office of the High Representative (OHR) - the agency monitoring the implementation of the Dayton Peace Agreements (1995), which also provides assistance to the state-building project. As scholars have argued, the logic of ethno-national partition - as a means to ensure peace - sat at the core of the agreements, creating long-lasting management problems in the country (e.g. Chandler, 2000; Soberg, 2008), and Mostar in particular, where two ethno-national communities contested each other's claim to the exclusive right to rule the city (Moore, 2013). Today, despite piecemeal 'unifications', the problem of Mostar continues to be in the inability of political elites to administer the city jointly. Accordingly, the city is often identified with a reluctance to change, and an inability to move beyond ethnicpolitics towards reconciliation.

After the forced re-unification in 2004, the OHR has intervened in Mostar's internal politics only when strictly necessary - for instance, to approve budgetary spending in lieu of a mayor ${ }^{1}$ - yet their frustration was unmistakable:

From the start, the City Council [in Mostar] has had the authority to amend the Statute [which was imposed] if they had a better idea on how to organise the city. But [...] political 
leaders blamed the international community for the city's troubles while taking very good care of themselves [...] [They] have kept citizens hostages of ethnic agendas as a way to perpetuate a status quo which only serves at keeping them in power. Neither party has put forward a positive vision for Mostar, of how the city can grow and prosper and serve as an engine of growth for Herzegovina (OHR, 2014).

Whereas the possibility for Mostar to change - to grow and prosper - is not dismissed, it seems unworkable as it depends on the willingness of political elites to collaborate (OHR, 2018). And exactly because the collaboration between international and local political actors has always been problematic, internationally-led strategies to produce change (i.e. to move forward with the state-building and peace processes) have steadily moved towards the nurturing of civil society as an alternative political protagonist (Goldstein, 2015; Jeffrey, 2013; Kappler, 2014; Keil \& Perry, 2015). Accordingly, since the end of the conflict, many international and local NGOs settled in Mostar to work on education, dialogue, and reconciliation. As Leontidou has noted, 'the emergence of NGOs was one of the interesting effect of Europeanisation [in Southern Europe]. They [NGOs] might have strengthened southern civil societies quite recently, but they do not necessarily tend to alternative cultures.' NGOs are often heavily integrated into political institutions - assuming strong, if not temporary, forms of organisational coherence - and act as advisors to governments with a view to funding or participation in order to safeguard 'social cohesion and the containment of conflict' (Leontidou, 2010, p. 1192). This is discussed at length by Kotlo who finds that citizens in Mostar consider NGOs as serving mostly their own personal interests, or the interests of sponsoring foreign countries (Kotlo, 2005, pp. 57-58). It also resonates well with Jeffrey's (2013) argument that the international project of empowering civil society in $\mathrm{BiH}$ has promoted a fierce competition among NGOs as they scramble to secure funding (less and less available) to maintain jobs, often shifting their main goal from improving society to ensuring their survival. Other scholars, like Fagan (2006), have also argued that the impact of NGOs' projects is limited until the Constitution is reformed. This is because the entire political system is based upon the principle that ethno-national groups must be protected, and the assumption that ethno-national elites will sooner or later agree to collaborate. In other words, despite the possibility that the activities and projects developed by NGOs might produce positive outcomes, their long-lasting effects are limited. For instance, organizations working with youth might be successful in creating spaces of inter-ethnic dialogue, but this will not change the fact that young people are schooled and socialized largely in ethnically-homogeneous spaces, whose righteousness is never challenged because it is constitutionally safeguarded (Laketa, this special issue). Of course, such an observation does not diminish the value of inclusive projects but rather presents a more critical assessment on the complexities and specificities of Bosnian transitional process as elaborated in this Special Issue by Djurasovic.

Since 2009, I have been researching grassroots activism in Mostar to explore the geo-political imaginaries of individuals who work largely outside institutional or official NGO networks and, as such, are also able to push forward more radical political projects such as the re-imagining of the future of Mostar outside ethno-national boundaries. This means, for instance, to withdraw their participation from ethno-national politics to create alternative political communities (Carabelli, 2018). The radical intent of such stands must be appreciated in relation to the specific context of Mostar in which politics has been articulated as a matter of protecting and reinforcing ethno-national groups, which are always produced as already 
antagonist because they compete for power, territory, and recognition. In this paper, I wish to re-engage with my previous work and delve further into the analysis of the relationship between grassroots activism and social change. It should be noted that grassroots activism in $\mathrm{BiH}$ has gained more attention recently, in the eve of the 2014 mass mobilization; the first time in the history of the country were people took the streets to demand change and to protest against the political elites that have administered the country since its independence (see Kurtović, 2018a; Kurtović \& Hromadžić, 2017; Murtagh, 2016). As Kurtović writes, the importance of the 2014 uprising is in the way they signal the re-emergence of grassroots activism 'as the pivotal point for thinking about the possibilities and promise of political transformation' precisely because they appear to

liberating the people from their association with both primordial nationalism and revolutionary terror, while also rendering them into the central pillar of hope for more immediate unmediated and less alienated forms of political community that could remedy the current disenchantment with both liberal (and illiberal) democracies. (2016, pp. 45-46)

Although this article does not engage with the 2014 protests directly, for many of my respondents in Mostar, the protests remain an important milestone in their struggle to gain visibility as alternative political voices at the national level. However, the protests ended, and their radical call for change remains unanswered, which frustrates all of my interviewees in Mostar. And yet, they seem to agree - to different degrees - that change is still possible as they continue to work on multiple projects to intervene in the political, and fight corruption and injustice in a city they love and wish to see flourish. This very attachment to the idea that change is still possible and worth fighting for was the primary reason for this project to develop as it did: I was interested to discuss with activists in Mostar how this change is still possible. I found it useful to think about change in relation to how Hardt and Negri conceive love as a political concept; love moves the multitude - the insurgent community - and it becomes the ultimate motor for change. Love allows Hardt and Negri to re-think political projects of radical change not as interestdriven (what can we gain from change), but rather as emerging through affective bonding and relationalities. For Hardt and Negri, but also Berlant (2011, 2015), love is 'transformative, a key site for a collective becoming-different, that can help inform alternative imaginaries' (Davis \& Sarlin, 2011). For Berlant, love 'is always about violating your own attachment to your intentionality, without being anti-intentional' (Davis \& Sarlin, 2011). In other words, love stands in as an affective power that helps to bring different subject experiences into relationality with one another, thereby blunting the absolute intentionality of any given individual, while negotiating new possibilities for other forms of intentionality and agency. For Hardt and Negri, in turn, 'the power of love is the constitution of the common and ultimately the formation of society', which does not proceed by reducing political singularities 'to form a uniform society', but exists as a mode of collective being that 'has to be learned and new habits have to be formed through the collective organization of our desires, a process of sentimental and political education' (Hardt \& Negri, 2009, pp. 195-196). These authors converge on the premise that love 'organises relationality through models of incoherence and multiplicity' (Davis \& Sarlin, 2011). To consider love in my research allows me to re-engage with ongoing struggles less as a matter of assessing their impact in relation to existing structural limitations and more as a means to explore the affective resonance of activism; is it love that 
keeps people moving in a city where the possibility of change seemed to have been exhausted? If so, how does love produce spaces of alterity where radical projects for change can grow stronger? How does love (dis)organize the local activist scene? To further this line of enquiry, I embrace Berlant's proposition to engage with non-sovereign modalities of agency, which challenges the notion of agency as a singular, calculating and purposeful mode of action by underscoring often-ambivalent affective and relational ways of being (cf. Berlant, 2007). This move opens up the possibility to understand activist projects not as coherent or organized movements demanding change, but rather as different projects that co-exist without continuity or intentionality. Such a position draws on Hardt and Negri's re-conceptualising of the activist, insurgent, community as a mutant configuration of demands, struggles, and battles against the neoliberal order that does not need to find structure or hierarchies to operate successfully. The multitude does not seek internal consensus. Rather, it produces internal support networks that function despite internal differences because love enables new kinds of relationalities that constantly negotiate such differences. This also means thinking about the agency of activists not as 'a property of human consciousness or privilege of the sovereign subject, but located in an encounter or relation, registering the constitutive co-implication of the many bodies that make worlds' (McManus, 2011). Ultimately, a focus on love allows me to attend to activist projects in Mostar in their generative capacity to open up opportunities to create new bonds and networks of solidarity and support in the city. Thus, the article discusses the possibility of change by considering love as the propeller of transformation, and it contextualizes Hardt and Negri's theoretical claims in relation to activist testimonies. I discuss interviews I conducted with local activists to explore how their activities and movements in the city (what they do to shake the unbearable political stasis) 'can resonate, in non-intentional, sometimes unpredictable and capricious ways, into agential orientations and sensibilities, and it is the nature of that transition or passage of affect that is crucial to mapping ambivalence' (Mc Manus, 2011). In this way, I locate the possibility of change in the everyday and by focusing on 'what's not trainable about people, who are always creating folds of beingotherwise in a way that stretches out and gives unpredicted dimensions to historical and subjective experience' (Berlant, 2009, p. 263 in McManus, 2011). I should clarify that I am critical of narratives of love as the solution for antagonism, fractures, and hatred (which is part of much charitable work in the city) and I am more attuned to understandings of activism as a form of love because love means 'to have patience for what isn't working [...] to be elastic and to try new incoherence' (Berlant, 2011b, p. 685). As the interviews show, activists' concerns are very different - from the environment, to fighting corruption, or championing mental health - but their combined actions shape a strong and relatively united response to the overwhelming sense of immobility that seems to characterize the political and social life of the country in general, and Mostar in particular. Presenting their complaints, struggles, and strategies to achieve change, I explore several interconnected issues organized in two main sections. Firstly, I ask what it means to be an activist in Mostar and what activism is ultimately for. Secondly, I explore how change is envisioned from the grassroots and how it is pursued through the lens of love. Overall, this article explores the possibilities afforded by love in creating new subjectivities that are supportive of radical change despite operating in a city whose entire political infrastructure supports ethnic division and social immobility. 


\section{A short methodological reflection}

I began researching Mostar's grassroots cultural activism in 2009 and I continued to contribute to cultural projects designed by Abart, a platform for art production and urban research, until 2012 (Carabelli, 2018, pp. 123-171). When I returned to Mostar in July 2018 to conduct new interviews for this article, my questions were informed by my personal experience of working in a local grassroots organization. Being aware that the very concept of activism (and being an activist) is contested in Mostar, I asked my respondents for their own definition of activism, which, they all agree, refers to those who act upon the realization of problems voluntarily and independently from the agendas of mainstream political actors (I discuss this in more detail in the next section). As we will see, many of my respondents are ambivalent with the label of 'activist', but I have decided to continue using this term because it signals the desire to move, to be active, and to activate resources that could produce meaningful change in the present of the city. I therefore use the term activism to address the challenges and potentials held by the very process of being active in a place where (political) movement is seemingly unimaginable.

I interviewed nine individuals who operate in very different spheres of political activism: mental health promoters, environmental activists, cultural practitioners, youth organizers, investigative journalists and anti-corruption watchdogs. Some I have known for some time, during previous periods of field research, whilst others were contacted because of their prominence in the local activist scene (for instance, because they held leadership roles during the 2014 protests). All interviews took place in Mostar, in July 2018 and the names of the interviewees have been changed to protect their anonymity.

The sample of interviews presented here is by no means exhaustive, or systematically representative of progressive politics in Mostar. Rather, what I present offers an exploratory research into the potential of thinking love as the motor for grassroots change. Accordingly, I did not approach these interviews as simply the collection of raw data such as the details of individual battles being fought. Rather, I asked my respondents to re-engage with their political activism in order to conceptualize what it means to move in a place of immobility. I asked what keeps them going, the reasons behind their daily engagement, and the meanings that social change take in their own terms - how do they imagine a better future and what steps need to be taken for those imaginaries to become more concrete? The interviews were semi-structured and allowed for my respondents to comment on my questions and/or re-phrase my queries to focus more on what they felt was relevant in understanding contemporary activism in Mostar, which they often did. Crucial to my interviews was to discuss love and how (if) love resonates with my respondents' experience of their activism in Mostar. With the few respondents who were familiar with Hardt and Negri's work on love, I discussed the implications of thinking about love as a political concept in Mostar and with others - less familiar - I asked to comment on the possibility of love to work as a political force that shapes their action.

\section{What is activism in Mostar?}

I was aware from my previous research that the term 'activism' remains contested in Mostar. And in fact, all my respondents showed ambivalence in identifying with it. In this section, I attend to this ambivalence to explore their reasonings in relation to 
Hardt and Negri's concept of love as the force that propels radical change outside profitdriven projects. Petar, a journalist and one of the most radical voices, articulates well what appeared as a shared sentiment among the interviewees:

I think that all people who work in the society at any level and especially if they do it for reasons that are self-motivated ... I mean ... they don't get funds from a donor, they can be considered activists. The problem with sponsored activism is that usually people who are funding are setting the tempo and the rhythms of the general discourse so, let's say ... for four years we do activism on Roma, for another four years on unprivileged women, and then we switch to the problems of rural areas. What I mean is that you eventually ask yourself if this makes sense at all ... why do we want to participate in someone else's agenda, which might as well not resonate with the problems we see as urgent in our society?

Sanjin, the co-founder of a non-for-profit, socially-conscious bicycle-repair shop that doubles as community-catalyst, voices his discomfort with activism and reacts to my question by stating that what he does is, in fact, not activism - 'It's my way of life', he says, almost annoyed. Attempting to distance himself and what he does from activism, he continues:

What we do might look like activism because we do something that is useful, if you want, for society but ... it's more that we like to fix bikes ... I am not saying that what we do is not activism but if you call it like that then it sounds commercial ... those who call themselves like that [activists] they just make money out of it ...

It's clear from these extracts that contested ideas surrounding the meanings and practice of activism revolve around issues of independence, autonomy of organization, and the everyday practicalities of political action that are just as much associated with the concept 'activism' as with any major social movement. With respect to the first of these ideas, it is little wonder that activism in Mostar puts a premium on freedom of action away from those agendas and institutions that led, so far, to post-war negotiations but may not necessarily engage with the everyday needs of the citizens, which emerge irrespective of political agendas. Overall, the sense that the grassroots level is the only independent space from which to enact change is also a symptom of the failure of the existing political system to initiate and sustain a dialogue with its citizens, and it amplifies the desire to initiate transformation from the grassroots. Crucially, my respondents see their actions as directed to solve problems as they become apparent and urgent in society. As such, their initiatives do not respond to pre-existing political agendas of change or societal improvement but shape relationally to what they see becoming urgent. Another important aspect of the ambivalence of activism is that it cannot be motivated by financial gain (thus becoming a profession, for instance). Zoran, an environmental activist, explains this well:

I might consider myself an activist but I don't call myself that ... Activism has become an empty word for me... Many of these activists just care about themselves instead of society; they want to be successful and reach goals [he sighs]. My girlfriend and I created a commune, far from the city, where people can come together to rest and clean their souls ... the city is corrupted.

Surely, Zoran's decision to leave the city and establish a commune speaks loudly about his resentment at urban activist circles that prioritize their personal gain (be it financial or in social status) to the common good. Interestingly, Zoran mobilizes the notion of selfless care as fundamental to his activism. This means to take care of the people and things 
around him without financial gain. And this is exactly what Hardt proposes; that the multitude 'substitute[s] love for money or property as the means for organizing the social [because this can] open up new social and political projects' (Davis \& Sarlin, 2011). Zoran suggests the need to re-create a sense of community (like the commune he co-established) where individuals can re-gain control of their lives and create alternative spaces that reject the corruption he associates with the city. Professional (NGO) care providers work with a different - commodified - notion of care, which negates what he sees as the true spirit and spring of communal life. This idea of care strongly resonates with 'love' as a political concept, which for Klein is 'the discipline of showing up for one another and for the collective good, time and time again' (in Penny, 2017). As such, Zoran is already re-articulating love as a political concept that 'reorient[s] political discourses [by] challenging conventional conceptions that separate the logic of political interests from our affective lives and opposes political reason to the passions' (Hardt, 2011, p. 676).

Being an activist in Mostar means to take care of the city - to fix its concrete problems as Sanjin argues - so that it can flourish. But it also entails the desire to instil a sense of community that embraces care for each other despite persistent narratives of division and antagonism, as Zoran urges, and without the prospect of gain that stigmatizes professional activists (NGO workers) in the eye of my respondents. When I ask Zoran about the guests at the commune, he explains that they are very different for provenance, age, life stories, and reasons to be there. Yet, Zoran believes in this project as activism because it allows individuals to take a break from their lives and re-think about their positionalities in the world. Zoran is not educating his guests to follow his life's principles because he believes firmly that we are all on different paths to understand how we can contribute to make this a better world. Zoran's desire to care and attend for the commune converges with Hardt and Negri's more expansive notion of 'love' as a political force, which 'not only ... mark[s] rupture with the existent and creation of the new, but also it is the production of singularities and the composition of singularities in a common relationship' (Hardt \& Negri, 2009, p. 183). For Hardt and Negri, love centres exactly on the production of the common and social life because love 'composes singularities, like themes in a musical score, not in unity but in networks of social relations' (2009, p. 184). And yet, paradoxically perhaps, the political concept of 'love' does not take on a singular form, in which it is everywhere and always a process of mutual togetherness. Love can also be refracted through the politics of exclusion and homogeneity. Indeed, at the very core of nationalism exists a kernel of love - the love for one's nation, and a hatred for those that do not belong $(2009$, p. 182). This 'poison of identitarian love... hinders and distorts love's productivity by forcing it constantly to repeat the same' $\left(2009\right.$, p. 183). ${ }^{2}$ For Hardt and Negri, it is through '[p] romoting encounters of singularities in the common [that] ... is the primary strategy to combat love corrupted through identity and unification' (2009, p. 184).

Zoran, as all the other activists I spoke to, seems to agree that difference in the city should be promoted rather than annihilated because activists embody this difference. Activism in Mostar is, in fact, about creating spaces that are inclusive of people who reject ethno-nationalist agendas - those who are different and yet do not constitute a homogeneous group or movement. In other words, Zoran embraces love as the transformative force that brings the insurgent community together through mutual care without seeking to impose change on anyone. Love dissociates flourishing from self-gain and re-attaches it 
to the desire for the common (shared) good. In this sense love is a propeller, the force that moves people together, and this, in Mostar, means to become active (despite political immobility) for the love of the city and its (not-corrupted) citizens. Nevertheless, the road to change and social transformation is beset by contradictions, not least with respect to how activists in Mostar negotiate the terrain of identitarian love, even as they attempt to move beyond it. In other words, post-identitarian discourses are very appealing for those who refuse nationalisms, but they are also impossible to sustain indefinitely because national identities are a necessary resource, which allows one to gain or lose rights as a citizen in the divided city (Carabelli, 2018, pp. 102-109). In this sense, the horizon of post-identitarian politics works as a measure of justice, but living in the present means facing the reality of being always approached as an ethnic subject in the ethnically-divided city. In the next section, I address in more detail how activists envision change in relation to their activism and their expectations from the future.

\section{How does change look from the grassroots?}

Despite a general plea to see change in terms of destabilizing ethno-nationalism, my respondents assign different priorities to their activism, which also affect their imagination and understanding of how to pursue change. Zvonko has been running several grassroots associations for over a decade. He seems restless and works on many parallel projects involving medical care, responsible tourism, corruption, recycling, and park maintenance beside his full-time job. For years, he has been compiling a report evidencing the mismanagement of public money in Mostar. For him, the most important change would be to have an accountable political class:

People come here and ask me about the divided city ... I always say: the money gets stolen from all our pockets - all the same. Kids are raised to know that the problem is the ethnic conflict, to me it's always about the money ....

When I ask whether new political elections could bring about change, he tells that 'the question is about whether the next generation of politicians will be honest'. Zvonko believes that the people are corrupted, but the system could work. Similarly, Sanjin, talking about his political engagement through the bike repair shop, comments:

We can still do bigger things in the future ... you know ... there are no cycling routes in Mostar and we could bring that up to the administration ... but for that you need to study the law, you need to prepare ... right now we prefer to tackle concrete problems that we know how we can solve...

For Sanjin, even the most mundane activities can be thought of as planting the seeds of political change. His repair shop works as a space that forms a community around the shared interest in cycling. Similarly, to build new bike routes may (literally) open up new spaces through which to build relationships within and beyond the city limits. And deeper engagement with those institutional bodies that regulate such issues might even initiate the necessary steps of engaging political institutions, buildings networks through these activities, eventually leading to deeper considerations and reflections on how political power operates, and what kinds of strategies might be adequate to face them from the grassroots level. Thus, while these activities may appear as somewhat 
innocuous, they can also be seen as a form of non-sovereign agency in terms of how change may occur through slow accretion, via winding (perhaps obscure) paths, yet accumulating relational affective bonds with others that may produce results not anticipated by anyone.

Alma, a recently graduate psychologist who established an outreach programme in schools to talk about post-war traumas, tells me that she sees concrete progress in the groups of children she works with, but for her programme to become more effective on a larger scale - her association would need some official support (in financial and logistical terms). And, although the schools in Mostar have been very collaborative, there are limits to what her small association of volunteers can do: 'change needs to happen at the state level ... and it's not going to happen'. Petar holds strong opinions on the topic of change, stating assertively that 'nothing can be changed through elections'. Kasim, one of the most outspoken activists of the 2014 protests, seems to agree. He doesn't trust the local or international administrators. He sees change in the radical possibility of getting rid of them all and starting again from the needs of the people. He strongly believes that activism is about scale; it starts from a small place and it becomes global. 'The fight is contagious but only when you win', he says with a smirk. Petar and Kasim don't believe in the existing political system based on ethnic-politics. Rather, they both wish for more revolutionary strategies to destroy what exists, and to make space for a new system of grassroots self-management, which resonates with what Zoran has already started outside the city and claim back the importance of the Yugoslav socialist experience. ${ }^{3}$

These extracts give a sense of how the practice of change diversifies among the activists I interviewed; the scope of their activism converges around the need to fight ethno-nationalism but it diverges in political beliefs, affecting the ways in which change is imagined. Most importantly, whereas for some changes can happen via a reform of the existing political system, for others the system is absolutely untenable. Interestingly, none of them address this as an issue. When I ask about collaborations and networking, only a few seem interested, referring to existing exchanges they have had abroad - across the Balkans - as good practice. There seems to be no concern in creating stronger networks within the city to organize activism. In fact, my respondents emphasize the need to support each other without solving their ideological differences. If there is an action that requires participation or support, they all mobilize even though their individual political beliefs differ greatly. Surely, they are strongly committed to fighting the common enemy of nationalism, but what happens when their desires come together to compete, diverge, or claim priority? This immanent contradiction speaks to the notion of 'desire', which as Berlant writes, 'reaches towards something to which it can attach itself (Berlant, 2012, p. 20) and only once we can identify desire with the object of desire, the action of desiring undoes the present to produce a future that is different, a new space in which to be otherwise (Berlant, 2012, p. 65). The existence of multifarious desires deeply affects the strategizing of activism in Mostar. This became apparent from talking to Dejan, who believed in the protests until he witnessed the eruption of violence and left, feeling uncomfortable:

In one moment, everybody wanted to speak up [at the plenum], to say what should be changed, but so many of the issues presented were so stupid! I don't think that change... I mean, the revolution, is possible now ... in our society ... because there are too many problems and to give priority to any of these problems create fractures (emphasis added). 
Alin, who was also at the plenums, agrees with Dejan but adds that the issue was not the existence of multiple demands. Rather, the absence of a hierarchical structure to validate or dismiss such demands. Everybody was given the same right to speak up and Alin was very supportive of this until it didn't work because people didn't know how to be (and work) together.

Although I strongly perceive the sense that these activists all fight for the creation of spaces where other than ethno-nationalist discourses could be initiated, there is no clear direction for a cohesive discourse to take shape and emerge. In fact, there is no movement emerging from the individual campaigns enacted in Mostar. While there are no deep-seated fractures, the desire to be together (as a community-other) is often pursued separately. This recurring theme, which we might call the problem of 'unity in difference', remains unresolved in Hardt and Negri's account of love. Clearly, love as the constituent force of the commons 'involves not only destroying the corrupt institutions but also constructing new ones' (Hardt \& Negri, 2009, p. 370). Such transformative institutions are themselves conceived as spaces for the 'training in love', which 'create[s] a context for [singularities] ... to manage their encounters' (2009, p. 367). Yet such institutional forms are by their nature unstable (and perhaps undurable), for 'every time [they are] ... solidified in fixed vertical relations of power, love exceeds it and overflows its limits' (2009, p. 196). This calls into question Hardt and Negri's metaphor for love as a musical score acting in concert, because, perhaps, it overlooks the contradictory dynamic at play within an orchestral ensemble, which, just as with the building of an organized insurgency, entails 'laborious and contentious efforts of building unlikely coalitions and creating networks among different groups' (Çıdam, 2013, p. 42). This ambiguity is keenly addressed by Berlant, when she writes that 'a properly political love must be durable; it must provide a space, as well as time and patience to "deal with" the unease that difference and contingency tend to incite in the making and remaking of worlds' (quoted in Dole, 2012, p. 230). Considering the lack of direction I noticed, it is fair to say that the activist community in Mostar is learning to be together and to negotiate their differences - not to impose one's sense of direction, but rather to create a movement that acquires direction through the individual battles being fought independently. This again speaks to the non-sovereign agency contained within such networks, yet the fragility this entails for political organization (and this type of agency) requires, as Berlant suggests, patience, which means to wait attentively. In fact, patience and urgency became crucial players in the interviews I collected.

Zvonko is eager to tell me the exact details of the many research projects he has commissioned to evaluate the economic potentials of Mostar, even if I show interest in different topics. Zvonko wants me to know what areas should be prioritized to re-start the economy of Mostar because he has invested resources and time to produce this knowledge. Zvonko is the same person who organizes people to clear green areas because the administration delays doing it. Zvonko is a man of action but he waits for change patiently and this struck me as a contradiction worth exploring. He is aware of the importance of his work, but the city is not ready to acknowledge what he does - the current administration is irresponsive - yet there is still hope for the future; and so, he can wait. At the same time, he confesses that his son will study abroad soon because he wants for him a better life. Zvonko doesn't perceive this as a contradiction. On the opposite, he thinks we make decision according to what is best in the moment. Zvonko doesn't have the luxury to hold on 'principles'; he wants his son to live in Mostar and have the most rewarding life but this is not possible (yet). 
Zvonko is well aware of his non-sovereignty and he embraces it patiently. He can prove corruption in the current administration but no journalists would talk to him. And yet he is not defeated. He loves what he does and he is certain that Mostar will be (again) desirable place to live. The urgency of his activism isn't defeated by the lack of concrete results. Rather, he remains realistic, and prepares for failure. In this way, his 'Love reshapes memory, minimizing the evidence of failure, violence, ambivalence and social hierarchies that would otherwise make love a most anxious desire to end anxiety' (Berlant, 2008, p. 179). Also for Zoran change requires patience - 'the time is not ripe', he states. For instance, he tells of the many illegal activities he witnesses daily in the place where he settled the commune but this is not the right time to intervene. Movements, he says, need strategy, plans, and support. Acting without preparation means that any move will result in sure defeat so he holds off reporting crimes. He is aware of how this is perceived as contradiction to my eyes, but he has patience and can wait longer.

As Berlant suggests,

love and optimism foreground the sort of difficulties and investments involved in creating social change, understood as the construction of an attachment to a world that we don't

know yet, but that we hope will provide the possibility for flourishing. (Davis \& Sarlin, 2011)

All my respondents, asked whether they felt hopeful, concluded that nurturing hope is part and parcel of their daily activism because, in Mostar, people fear change and cannot be hopeful about it. Fear, for Alin, is (understandably) what stopped people from joining the protests. Fear is what limits the reach of activism in Mostar. Love and hope energize each other across activist experiences in Mostar to silence the lingering fear that moving too much will make activists lose what little they gained from accepting the normalization of crisis, which silences hope for a better future. Love is about inclusiveness but coexistence can be reached only through processes of open confrontation, mutual education and agonism that seem too dangerous within environments still characterized by fear; from the fear of police brutality that limit popular participations, to the fear of risking one's job, speaking truth to power, or the fear that by shaking the system too much another war might ensue. Indeed, if, as Balibar (1994, p. 5) suggests, 'fear of the masses' always entails a double meaning - a fear that the masses feel, and fear that the masses inspire within those who governs them - the case of Mostar evinces a radical imbalance between these two poles. And this imbalance surely complicates the already-unstable edifice of love, by infusing it with insecurity and confusion.

In this landscape of political and social impasse, the importance of those who mobilize to care for the city, to fix its problems, and to imagine how it could be improved become even more important. Surely, activism in Mostar hasn't led to tangible change, but the very fact that these more radical actors in civil society manage to create spaces where to imagine a more inclusive and just future is the cypher of the existence of a multitude that patiently shakes the foundation of Mostar's divisive and unjust political infrastructures.

\section{Conclusion}

The activists I have interviewed do not come together to form new organizations with clear agendas. Rather, they are singularities working independently but inclusively towards change. Their experiences also reveal how traditional political concepts lack the theoretical syntax with which to describe disparate singularities (not functionally linked) which challenges 
our traditional view of activists working in cohesively organized groups. Looking at activism from this angle doesn't discount the many instances of activism that takes a more institutional (or traditional) form; rather it exposes the need to find new vocabulary that explains new forms of incoherent and differently-organized activism. As the article suggests, the notion of love helps us explore the importance of activists whose work do not come together as a unified movement but rather address social change, justice and the possibility for a better future independently even though never antagonistically. As such, the article takes to heart Zoran's call for suspending all activities to re-connect with activism and find the force to care for all that is uncared for in the city wishing that a new movement could be born. Petar also believes that the time will come for new protests to start. This time, he hopes, there won't be any interference from international agencies and global actors. He believes that this country can produce something truly innovative in terms of self-management and he continues to work and educate people to it. Overall, the activists I interviewed are all involved in practices of space-production. They demand concrete spaces in which to exist outside ethnic politics, but they also fight for a space from which to become visible without being blackmailed, arrested or subjected to violence. Their fight for a different space addresses the need for a safe space (safe from ethnonationalist exclusivist violence) that materializes encounters. I associate this wish with love's expansive capacity to create space for new relational bonds. Specifically, a space that is conducive to movement and that allows desires to be confronted and negotiated, engender nonsovereign agencies that do not exist as autonomous subjects but as affective beings in relation to one another. In this sense, love becomes politically radical. Surely, the love connecting activists to the idea of change, to the ideal of re-building Mostar to become inclusive, progressive, and comfortable is palpable, and works patiently towards the re-framing of social life in the city. When Hardt discusses in an interview his interest in love as a political concept, he explains how 'in certain political actions, in certain political demonstrations [...] you have the feeling of something really like love' (Schwartz, 2009, p. 812). In the interviews I conducted, because of the more intimate setting, I couldn't feel the overpowering love and energy of mass protests, but I could identify, clearly, love as the attachment to one's political ideas that moves and becomes contagious. When I ask Zoran about love, he smiles:

When things are impossible you need a flame, which is love and it makes you move ... but love must be nurtured and kept clean, you need to take care of it if you want to see it flourishing ... the most important thing about the maintenance of love is to understand what kills it and avoid it ... you need to know the root problem, isolate it and then you can improve ...

This article has attempted to reflect upon this sentiment, in terms of how love as a political force takes shape within grassroots activism in a divided city. It seems that activists in Mostar are learning how to manage their love for change, which means to create spaces where not only supportive dialogue but also open debate could happen. Yet as with Hardt and Negri's concept of love, activism in Mostar is beset with ambiguities, fissures, contradictions and contingency. The terrain of singularities constituting activism in Mostar is far more diffuse and unconnected than that depicted in Hardt and Negri's Commonwealth. The variety of activism, from investigative journalism to bike repairs, speaks to the radical diversity of Mostar's grassroots, as well as the myriad problems encountered in the city. Yet uniting these disparate forces is the underlying desire to combat corrupted (ethno-national) love with a more transformative practice, as the 'love of the stranger, love of the farthest, and love of alterity' (Hardt \& Negri, 2009, p. 183). 
Departing from the specific case of activism in Mostar, this article also urges for research on divided cities to recalibrate, so that the possibility of change could become more central to our analyses. Other scholars have highlighted already the importance of looking at grassroots movements in divided cities. Nagle, for instance, writes extensively about supra-national groupings in Belfast and Beirut to emphasize how 'non-sectarian movements provide important alternatives to the politics of division prevalent in divided societies' (Nagle, 2016, p. 3). In this article, I claim that we should also pay attention to what has not yet become a movement, to what lacks cohesion, such as certain forms of activism in Mostar, so that we can re-think change as something that happens in the cracks, and takes momentum through love as an open terrain of agency.

\section{Notes}

1. Last election in Mostar took place in October 2008 and all subsequent attempts at electing a mayor failed for internal disagreements (Bose, 2017, p. 202). In April 2009, civil servants couldn't be paid because there was not an approved budget for city spending. This prompted the OHR to intervene and approve a budget until new elections, which were supposed to happen in 2009 but didn't. In 2011, the Constitutional Court of $\mathrm{BiH}$ established that the voting system in Mostar is unconstitutional but because of the failure to implement instructed changes to the electoral law, Mostar was the only city in the country where the national 2012 elections couldn't take place. The mayor elected in 2008 remains to these days the acting-major of the city.

2. I agree with Wikinson's critique (2017) of this passage when she states that identitarian love is also necessary for radical activism, especially among minority groups that need affirmation. Yet, in this article, Hardt and Negri's definition of identitarian love works well with the case of Mostar, in which the kernel of injustice revolves around identitarian (ethno-nationalist) divisions.

3. In this paper, I don't focus on the resonance of Yugoslav socialism in contemporary activism because not all my interviewees mobilized this historical legacy to formulate modes of political engagement. Surely, this remains an important theme to be explored. For an indepth discussion on how activists reclaim and activate the unrealized potentials of Yugoslav socialism, see Kurtović (2018b).

\section{Acknowledgement}

I would like to thank Srdjan Gavrilović for his support in planning and organizing my fieldwork in Mostar. Rowan Lubbock, Maria Andreana Deiana, Renata Summa, Aleksandra Djurasovic and the anonymous reviewers for their challenging comments that helped re-shaping this article.

\section{Disclosure statement}

No potential conflict of interest was reported by the author.

\section{Notes on contributor}

Giulia Carabelli is an interdisciplinary urban scholar interested in ethnic conflicts, the construction and contestation of national identities and grassroots activism especially in South-East and Central Europe. Her first book, The divided city and the grassroots. The (un)making of ethnic divisions in Mostar was published in 2018 by Palgrave in the Contemporary City series. 


\section{ORCID}

Giulia Carabelli (D) http://orcid.org/0000-0001-7427-3923

\section{References}

Balibar, E. (1994). Masses, classes and ideas: Studies on politics and philosophy before and after Marx. London: Routledge.

Berlant, L. (2008). The female complaint. Durham: Duke University Press.

Berlant, L. (2011). A properly political concept of love: Three approaches in ten pages. Cultural Anthropology, 26(4), 683-691.

Berlant, L. (2012). Desire/love. New York: punctum books.

Berlant, L. (2015). A momentary anestesia of the heart. International Journal of Politics, Culture, and Society, 28, 273-281.

Berlant, L. (2007). Slow death (Sovereignty, Obesity, Lateral Agency. Critical Inquiry, 33(4), 754-780.

Berlant, L. (2009). Neither monstrous nor pastoral, but scary and sweet: Some thoughts on sex and emotional performance in Intimacies and What do Gay Man Want? Women \& Performance: A Journal of Feminist Theory, 19(2), 261-273.

Berlant, L. (2011). A PROPERLY POLITICAL CONCEPT OF LOVE: Three Approaches in Ten Pages. Cultural Anthropology, 26(4), 683-691.

Bose, S. (2017). Mostar as microcosm: Power-sharing in post-war Bosnia. In A. McCulloch \& J. McGarry (Eds.), Power-sharing. Empirical and normative challenges (pp. 189-211). Abingdon: Routledge.

Carabelli, G. (2018). The divided city and the grassroots. The (un)making of ethnic divisions in Mostar. Singapore: Palgrave.

Chandler, D. (2000). Bosnia. Faking democracy after Dayton. London: Pluto.

Çıdam, Ç. (2013). A politics of love? Antonio Negri on revolution and democracy. Contemporary Political Theory, 12(1), 26-45.

Davis, H., \& Sarlin, P. (2011). 'On the risk of a new relationality': An interview with Lauren Berlant and Michael Hardt. Reviews in Cultural Theory (2.3). Online Publication. http:// reviewsinculture.com/2012/10/15/on-the-risk-of-a-new-relationality-an-interview-with-laurenberlant-and-michael-hardt/

Dole, C. (2012). Revolution, occupation, and love: The 2011 year in cultural anthropology. American Anthropologist, 114(2), 227-239.

Fagan, A. (2006). Civil society in Bosnia ten years after Dayton. In D. Chandler (Ed.), Peace without politics? Ten years of state-building in Bosnia (pp. 100-114). London: Routledge.

Goldstein, P. (2015). Grassroots narratives and practices of diversity in Mostar and Novi Sad. In T. Matejskova \& M. Antonsich (Eds.), Governing through diversity: Migration societies in post-multiculturalism times (pp. 104-124). Basingstoke: Palgrave.

Hardt, M. (2011). For love or money. Cultural Anthropology, 26(4), 676-682.

Hardt, M., \& Negri, A. (2009). Commonwealth. Cambridge: Harvard University Press.

Jeffrey, A. (2013). The improvised state. Chichester: Wiley-Blackwell.

Kappler, S. (2014). Local agency and peacebuilding. EU and international engagement in BosniaHerzegovina, Cyprus and South Africa. Basingstoke: Palgrave.

Keil, S., \& Perry, V. (Eds.). (2015). State-building and democratisation in Bosnia Herzegovina. Burlington: Ashgate.

Kotlo, R. (2005). The role of non-governmental organisations in building trusts and good governance in Mostar. Retrieved from Policy Development Fellowship Programme Central European University website: http://pdc.ceu.hu/archive/00002638/

Kurtović, L. (2018a). Conjuring 'the people'. The 2013 Babylution protests and desire for political transformation in postwar Bosnia-Herzegovina. Focaal, 2018, 43-62.

Kurtović, L. (2018b). An archive to build the future: The recovery and rediscovery of the history of socialist associations in contemporary Bosnia-Herzegovina. History and Athropology, 30(1), 20-46. 
Kurtović, L., \& Hromadžić, A. (2017). Cannibal states, empty bellies: Protest. History and political imagination in post-Dayton Bosnia. Critique of Anthropology, 37(3), 262-296.

Leontidou, L. (2010). Urban social movements in 'weak' civil societies: The right to the city and Cosmopolitan activism in Southern Europe. Urban Studies, 47(6), 1179-1203.

McManus, S. (2011). Hope, fear, and the politics of affective agency. Theory \& Event, 14(4). http:// muse.jhu.edu/article/459120

Moore, A. (2013). Peacebuilding in practice. Local experience in two Bosnian towns. Ithaca: Cornell University Press.

Murtagh, C. (2016). Civic mobilisation in divided societies and the Perils of political engagement: Bosnia and Herzegovina's protest and plenum movement. Nationalism and Ethnic Politics, 22, 149-171.

Nagle, J. (2016). Social movements in violently divided societies. London: Palgrave.

OHR. (2014). HR urges BiH parliament leadership to ensure holding elections in Mostar this year [Press release 03 July 2014]. Retrieved from http://www.ohr.int/? $p=31593$

OHR. (2018). High representative meets Council of Europe 'Congress Reflection Group on Mostar'. [Press release 25 June 2018]. Retrieved from http://www.ohr.int/? $p=99666$

Penny, L. (2017, July). Take back the power: Naomi Klein. New Statement. Retrieved from https:// www.newstatesman.com/2017/07/take-back-power-naomi-klein?fbclid= IwAR0ZHrCxagX1BiKsUVMQqgZaAonPt5KnQiKtwi6VtxNzlYqzJ5w3x_RmOEc

Schwartz, L. (2009). A conversation with Michael Hardt on the politics of love. Interval(le)s, II.2III. $1,810-821$.

Soberg, M. (2008). The quest for institutional reform in Bosnia and Herzegovina. East European Politics and Societies: and Cultures, 22(4), 714-737.

Wilkinson, E. (2017). On love as an (im)properly political concept. Society and Space, 35(1), 57-71. 